\title{
English as a foreign language-teachers' perspectives on implementing online instruction in the Iranian EFL context
}

\author{
Reza Dashtestani* \\ Department of Foreign Languages and Literature, University of Tehran, Tehran, Iran
}

(Received 20 November 2012; final version received 29 November 2013)

\begin{abstract}
This study set out to explore Iranian English as a foreign language (EFL) teachers' perceptions on the implementation of online EFL instruction. A mixedmethods design, including semi-structured interviews and questionnaires, was employed for the specific purposes of this study. A total of 242 EFL teachers participated in the questionnaire phase of the study. In addition, 46 EFL teachers participated in the interview phase of the study. The teachers worked at a number of universities, schools and language-teaching institutions in Iran. Results suggest that although the Iranian EFL teachers adopted moderately positive attitudes towards the implementation of online instruction, the majority of them preferred blended instruction to online instruction. At the same time, the study revealed that the implementation of online EFL instruction in Iran is challenging due to a number of perceived impediments and obstacles. The most considerable perceived challenges to the implementation of online EFL instruction comprise lack of online facilities and resources, lack of interaction in online instruction, cultural resistances to online instruction and teachers' limited knowledge of online instruction. The findings of this study provided crucial insights into teachers' perspectives on a number of measures that can be adopted to facilitate the integration of online instruction in the EFL context of Iran. The findings would provide valuable insights for educational authorities and course designers to integrate online instruction into the EFL curriculum.
\end{abstract}

Keywords: online instruction; blended instruction; teachers' attitudes; challenges; English as a foreign language

\section{Introduction}

In recent years, educational decision makers and course designers from a wide range of educational institutions and universities have expressed growing interest in the implementation of online instruction (Beatty and Ulasewicz 2006; Dawley 2007; Fish and Gill 2009). Accordingly, the implementation of online EFL instruction has gained increased popularity in language-teaching and -learning contexts (Hubbard 2008; Shin and Son 2007; Stickler and Hauck 2006). Online instruction would offer a plethora of benefits and merits for various educational stakeholders. The benefits of online instruction include the opportunity for ubiquitous learning, convenience, cost-effectiveness, provision of educational opportunities for learners and instructors, accessibility, learner-centredness and improvement of students' higher order thinking

\footnotetext{
*Corresponding author. Email: rdashtestani@ut.ac.ir

Research in Learning Technology 2014. (C) 2014 R. Dashtestani. Research in Learning Technology is the journal of the Association for Learning Technology (ALT), a UK-based professional and scholarly society and membership organisation. ALT is registered charity number 1063519 . http://www.alt.ac.uk/. This is an Open Access article distributed under the terms of the Creative Commons CC-BY 4.0 License (http:// creativecommons.org/licenses/by/4.0/), allowing third parties to copy and redistribute the material in any medium or format and to remix, transform, and build upon the material for any purpose, even commercially, provided the original work is properly cited and states its license. 


\section{R. Dashtestani}

(Bijeikienè, Rašinskienè, and Zutkienè 2011; Britt 2006; Hill 2002; Hofmann 2002; Kim and Bonk 2006; Petrides 2002).

Some experts of educational technology and online instruction contend that the implementation of online instruction might create limitations and challenges. Most importantly, lack of interaction between the instructors and students might be one considerable challenge of online instruction (Song et al. 2004; Vonderwell 2003). Another significant barrier to implementing online instruction is that instructors should develop and prepare appropriate materials for online instruction while this issue places a considerable demand on instructors (Reeves and Brown 2002). Providing timely and effective feedback to students would create concerns for teachers in online instruction (Taylor 2003). Moreover, delays in providing feedback and responding to students' questions would cause misunderstanding and frustration. As a significant impediment, Madaus (2013) argues that most instructors would not possess the necessary skills and expertise required for implementing online instruction. The final restriction of online instruction is lack of interaction in online courses and failure to meet realistic needs of students (Carnevale 2004; Hampel and Hauck 2004).

Despite these challenges and obstacles, online instruction has continued to be a robust and efficient approach to learning and teaching from the perspectives of many teachers and students (Li and Irby 2008). In addition, several scholars of language teaching have pointed out that the use of the Internet and online tools would increase EFL students' autonomy and facilitate their learning (Levy 2009; Shin and Son 2007; Son 2011; Warschauer 2010).

\section{Literature review}

Even though there is an abundance of research directed towards students' perceptions on the implementation of online instruction in a wide range of educational contexts (e.g., Allen et al. 2002; Hammonds 2003; Irani and Telg 2002; Poole 2000; Richardson and Newby 2006; Song et al. 2004; Thurmond et al. 2002), the issue of teachers' perspectives of online instruction has remained mostly uninvestigated.

Interestingly, results of several studies related to teachers' perspectives on online instruction in educational contexts are indicative of teachers' positive attitudes towards the implementation of online instruction. Specifically, some studies have been undertaken to assess teachers' and students' perspectives on online instruction using social constructivist approaches (e.g., Can 2009; Gold 2001; Lavooy and Newlin 2003; Sam, Wah, and Leong 2007; Woo and Reeves 2007). The findings of research related to social constructivist approaches to online instruction have indicated that the majority of educational stakeholders, including teachers, adopt positive attitudes towards these approaches to online instruction. A couple of studies have also been carried out to assess teachers' attitudes towards the implementation of online instruction (Benson, Anderson, and Ooms 2011; Koo 2001; Puteh 2002; Yusof et al. 2011). Generally, the results of these studies showed the positive attitudes of teachers towards online instruction. However, previous research has indicated that online instruction is not without limitations. Technical problems of online courses, lack of teachers' computer literacy, lack of teachers' training for online instruction and lack of interaction are the major challenges of online instruction from the perspective of teachers.

Even though, in language-teaching contexts, a plethora of studies have examined students' attitudes towards online EFL instruction (Aydin 2007; Chenoweth and Murday 2003; Chou 2010; Isman and Dabaj 2004; Scida and Saury 2006; Yang 2001), 
limited research has been conducted on teachers' perceptions of online language instruction (e.g., Bijeikienè, Rašinskienè, and Zutkienė 2011; Hampel and Hauck 2004; Murday, Ushida, and Chenoweth 2008; Shin and Son 2007). Based on the findings of the relevant literature, it can be concluded that the majority of language teachers adopt positive attitudes towards online instruction. Easy access, learnercentredness and communicativeness are significant merits of online EFL instruction based on the findings of the previous literature. On the contrary, the challenges of online EFL instruction included language teachers' lack of computer literacy and knowledge of online instruction, lack of facilities to implement online instruction and lack of interaction in online language-teaching courses. With regard to the previous literature, relevant limitations and obstacles should be removed to enable EFL teachers to teach EFL online.

Concerning online instruction in Iran, Gharehbakloo (2005) argues that few universities and schools have adopted online instruction approaches despite the fact that there are several challenges to the implementation of online instruction. These challenges include lack of access to high-quality Internet services, low levels of computer skills, low speed of the Internet, lack of online teaching materials and resources and difference between degrees received from traditional universities and online universities. In addition, Fathi Vajargah and Khoshnoodifar (2013) believe that the Iranian educational curriculum should be internationalised. They point out that implementing online instruction and technology-enhanced approaches to instruction would facilitate the internationalisation of the educational system of Iran. It has been recommended that possible barriers to internalisation and online instruction be eliminated in the Iranian educational context. The issue of facilitating the implementation of distance and online instruction in Iran has been emphasised in several studies (Ghafari and Molaei 2011; Goodarzi et al. 2012; Khasseh, Moghaddam, and Jowkar 2009; Tavakoli Khomeini 2009). Furthermore, teachers occupy fundamental roles in the use of technology in language-teaching contexts even though very limited research has been directed towards their attitudes towards the use of technology for language teaching in Iran (Dashtestani 2012). Therefore, the current study was an attempt to provide insights into language teachers' perspectives on the implementation of online instruction in language-teaching courses in Iran. The findings would have implications for facilitating the implementation of online instruction in EFL contexts. To achieve the above-mentioned aims, the research asks the following specific questions:

(1) What are the attitudes of Iranian EFL teachers towards the implementation of online instruction?

(2) What are the perceptions of EFL teachers on the possible challenges to the implementation of online instruction?

(3) What are the perceptions of EFL teachers on strategies that should be adopted to integrate online instruction in the Iranian EFL curriculum?

\section{Methodology}

\section{Research design}

A mixed-methods design was adopted for the purposes of this study. More specifically, attempts were made to conduct a methodological triangulation through 


\section{R. Dashtestani}

the use of a mixed-methods design. First, the use of such a design provided both confirmatory and supplementary data, which enriched the findings and their interpretations. Second, since methodological triangulation is an effective approach to obtaining valid and comprehensive interpretation of the research data (Best and Kahn 2005), two instruments were employed to improve the validity of the instruments and interpretations of the findings in this study. As a result, qualitative data were collected using in-depth interviews and quantitative data were collected employing questionnaires. The qualitative and quantitative findings were then analysed and compared to provide rich and validated findings.

\section{Questionnaire development}

Initially, a Likert scale questionnaire was designed to investigate the attitudes of EFL teachers towards implementing online language teaching in Iran. The questionnaire was constructed and developed based on reviewing previous research on theories, practices and findings related to online instruction in EFL and educational contexts (e.g., Bijeikienė, Rašinskienė, and Zutkienė 2011; Corda and Stel 2004; Hampel and Hauck 2004; Murday, Ushida, and Chenoweth 2008; Sampson 2003; Scida and Saury 2006). The content of the items was examined by a team of three senior professors of Educational Technology and three senior professors of Applied Linguistics. The items were revised and improved based on the suggestions and recommendations made by the team of experts.

In addition, Cronbach's Alpha coefficients were calculated and the results showed high levels of reliability for the three sections of the survey $(\alpha=0.87,0.92,0.9$, respectively). According to Murphy and Davidshofer (2001), reliability indices more than 0.9 indicate a high level of reliability. In order to evaluate the construct validity of the questionnaire, an acceptable level of Kaiser-Meyer-Oklin (KMO) measure of sampling adequacy (section $1=0.77$; section $2=0.79$; section $3=0.69$ ) and Bartlett's test of sphericity (0.00) was achieved. Therefore, exploratory factor analysis (EFA) was run to establish the construct validity of the questionnaire (Anderson, Fisher, and Norman 2002). Specifically, the items of the first section of the questionnaire loaded on four factors. The second section of the questionnaire included three factors. The last section comprised two factors. The factor loading of $<0.30$ for each item was regarded acceptable and satisfactory.

Following the demographics items, a total of 31 items were included in the questionnaire. The first section of the questionnaire included items related to teachers' attitudes towards implementing online EFL instruction. The items of the second section were constructed to identify the challenges and limitations of online EFL instruction from the perspective of EFL teachers. Finally, teachers' perceptions of strategies to be adopted to implement online language teaching were explored through the inclusion of the last section of the questionnaire. Paper-based questionnaires were distributed and the teachers were invited to participate in the questionnaire phase of the study voluntarily.

As for the ethical considerations of the study, an informed consent letter was submitted to the teachers before their participation in the survey study. The consent letter was developed based on the guidelines of designing consent letters mentioned in Mackey and Gass (2005). Specifically, the consent letter was designed to provide sufficient information about the study for the teachers, comprehension of the aims of research and voluntary participation of the participants. The issues regarding 
anonymity and confidentiality were further taken into consideration and explained to the participants.

\section{Interview development}

Interviews were also used to enrich the results obtained from the survey study. A total of 46 EFL teachers accepted to take part in interviews. The responses of the participants were recorded during each interview session. The interviews were conducted throughout 6 weeks. The same panel of six professors validated the content of the questions of the interviews. Also, the same literature was used to construct the questions of the interviews. The interview questions were as follows:

(1) What are the possible benefits of online EFL instruction?

(2) What are the obstacles to the implementation of online EFL instruction in Iran?

(3) What types of strategies should be adopted to facilitate the inclusion of online EFL instruction in EFL curricula of Iran?

(4) Do you believe in the usefulness of blended EFL instruction or online EFL instruction for Iranian EFL students? Why?

(5) Do you think that you have adequate skills to teach in an online EFL instruction? Why do you think so?

\section{Data analysis procedures}

The data of the questionnaire were analysed through performing a descriptive analysis. The mean and standard deviation were presented for the data related to each item of the questionnaire. SPSS version 16 was employed for the data analysis. To ensure the reliability of the data analysis, two different coders (including the author) read the data obtained by the interviews and then transcribed them. The emerging themes, which were verified by the two coders, were analysed and reported. Excerpts from teachers' statements were included in the study.

\section{Sample}

The sample comprised 242 EFL teachers from eight different language-teaching institutions $(n=147)$, two universities $(n=39)$ and six high schools $(n=56)$ in the provinces of Tehran and Alborz, Iran. The teachers took part in the study in the summer of 2012. All participants had attended teacher training/education courses before their employment. In addition, 46 EFL teachers participated in the interview study. Since access to all schools, universities and language-teaching institutions was not possible for the researcher, a convenience sample was considered useful for the purpose of this study. The researcher selected those schools, universities and language-teaching institutions that were accessible. Moreover, in order to achieve a common understanding regarding the purpose of the study and the definition of online instruction, in the initial section of the questionnaire a definition was provided for online instruction based on the purposes and framework of the study. Those teachers who strongly agreed or agreed with the definition were included in the study. The teachers who disagreed or strongly disagreed with the definition provided were 


\section{R. Dashtestani}

excluded from the study and data analysis. Table 1 shows the characteristics of the sample group used in this study.

\section{Findings}

\section{EFL teachers' attitudes towards online instruction}

The survey. As Table 2 depicts, the EFL teachers held fairly positive attitudes towards online EFL instruction (total mean of the section =3.56). Updated materials, students' autonomy, improvement in students' motivation, time-efficiency, authenticity of resources, opportunities for international communication, learner-centredness, accessibility, use of different types of materials, use of multimedia and cost-effectiveness were the perceived merits of online EFL instruction reflected in the responses of the participants.

The interview. The responses to the first question of the interview regarding the merits of online EFL instruction showed the positive attitudes of the majority of EFL teachers. The teachers pointed out some benefits of online EFL instruction, including authenticity and variety of materials, promotion in students' motivation to learn, accessibility for all students, and time and energy efficiency. Excerpts of the participants' quotations confirm these positive attitudes:

One problem for many students is spending a long time on learning. Students who lack time to attend EFL courses can benefit from online EFL courses a lot. These courses will be accessible to all students. (Teacher 17)

Well ... the problem is that the current EFL courses which are based on traditional approaches to teaching EFL are not very motivating for EFL students. Using technology especially online EFL teaching might help language teachers to switch to more modern approaches to teaching and improve students' motivation and interest in learning a language. (Teacher 30)

\section{EFL teachers' perceptions of obstacles to the implementation of online instruction}

The survey. Based on the findings illustrated in Table 3, the EFL teachers regarded lack of online facilities, students' incompetence to use the Internet, cultural resistances to online EFL courses, lack of interactivity, possible negative attitudes of students towards online EFL instruction, and suitability of online EFL courses for autonomous students and not all students as the major barriers to the implementation of online instruction in EFL contexts.

Table 1. Participants' demographic information.

\begin{tabular}{lcc}
\hline Gender & Male $=98$ & Female $=144$ \\
\hline Average age & 34.4 & \\
Average years of teaching EFL & 8.7 & \\
Average years of using computers & 9.7 & \\
Average years of using the Internet & 7.6 & \\
University degrees & BA/BS: 172 & \\
& MA/MS: 66 & \\
& PHD: 4 & \\
\hline
\end{tabular}


Table 2. Teachers' attitudes towards online instruction

\begin{tabular}{lll}
\hline Number of participants =242 & Mean & SD \\
\hline Updated materials can be used in online EFL courses & 4.45 & 0.9 \\
Students will be more autonomous in online EFL courses & 4.24 & 0.79 \\
Online EFL courses enhance students' motivation & 4.23 & 0.83 \\
Online EFL courses are time-efficient & 4.1 & 0.9 \\
Authentic materials are used in online EFL courses & 4.04 & 0.99 \\
Learners can communicate internationally in online EFL courses & 3.98 & 1.06 \\
Online EFL courses are based on learner-centred approaches to teaching & 3.94 & 0.91 \\
Online EFL courses are easily accessible to students & 3.9 & 1.22 \\
Multimedia can be used in online EFL courses & 3.86 & 1.19 \\
Various types of materials can be used in online EFL courses & 3.83 & 1.3 \\
Online EFL courses are cost-effective & 3.72 & 1.22 \\
Online EFL courses will promote students' and teachers' computer competence & 3.3 & 1.2 \\
Online EFL courses are in line with experiential approaches to leaning & 3.26 & 1.29 \\
Online EFL courses provide equal opportunities for learners to learn English & 3.13 & 1.11 \\
Online EFL courses promote collaboration among students & 3.06 & 1.41 \\
Expansive feedback can be provided for students in online EFL courses & 2.97 & 1.24 \\
Online EFL courses are easy to be implemented & 2.37 & 1.4 \\
Online EFL courses are more interactive than traditional courses & 2.36 & 1.25 \\
\hline
\end{tabular}

Likert scales: 1 , strongly disagree; 2 , disagree; 3 , undecided; 4 , agree; 5 , strongly agree.

The interview. The EFL teachers were asked about the limitations which might impede the inclusion of online instruction. The majority of participants reported that there is a serious lack of online and Internet-based facilities in the Iranian EFL courses. This challenge was reported in the responses of 41 EFL teachers. Some EFL teachers asserted that some EFL students would not accept or trust online EFL instruction since they are accustomed to using traditional approaches to EFL teaching and would resist the change.

In response to the question regarding the adequacy of EFL teachers' skills for online instruction, most EFL teachers reported that they were not competent enough for the implementation of online EFL instruction. The EFL teachers seem to lack methodological and computer knowledge to teach English online. Some teachers

Table 3. Obstacles to the implementation of online instruction.

\begin{tabular}{lcl}
\hline$N=242$ & Mean & SD \\
\hline There is a lack of online facilities in EFL courses & 4.32 & 0.78 \\
$\begin{array}{l}\text { Students lack the necessary Internet-based skills to participate in online ELT } \\
\text { courses }\end{array}$ & 4.09 & 0.98 \\
& & \\
There are cultural resistances to the implementation of online EFL teaching & 3.87 & 0.94 \\
There is a lack of interaction in online EFL courses & 3.82 & 1.05 \\
Students do not have positive attitudes towards online EFL courses & 3.68 & 1 \\
Online EFL courses are just appropriate for autonomous students & 3.67 & 1.17 \\
There is not much teacher supervision over students in online EFL courses & 3.1 & 1.3 \\
Online EFL courses are not responsive to students' needs & 2.88 & 1.31 \\
Online EFL teaching is costly to be implemented in TEFL contexts & 2.82 & 1.21 \\
Online EFL courses place a lot of demands on EFL teachers & 2.58 & 1.13 \\
Online EFL courses are not motivating for students & 2.42 & 1.1 \\
\hline
\end{tabular}

Likert scales: 1 , strongly disagree; 2 , disagree; 3 , undecided; 4 , agree; 5 , strongly agree. 


\section{R. Dashtestani}

also stated that online EFL instruction is not suitable for all students and it can exclusively meet the needs of some specific groups of students. For example:

We lack basic technological facilities in our EFL courses. How do we expect that we can run online EFL courses? (Teacher 7)

I reckon students will not feel comfortable in online EFL courses. This might be because of their lack of ICT competence or their distrust in online EFL courses. I sometimes see some students who are not able to perform some basic computer operations and it's a shame. So it's not only the matter of teaching but the matter of learning as well. (Teacher 41)

Online language teaching requires some specific skills on the part of EFL teachers. We don't know how to run these courses efficiently. I believe this problem discourages teachers from teaching EFL online. (Teacher 29)

Not all students will benefit from online courses. We should first consider students' needs and then plan to teach EFL online. (Teacher 33)

\section{Strategies to be adopted to include online instruction}

The survey. As Table 4 shows, it appears that some strategies, including improving online facilities, training on teaching methodologies of online EFL courses, combining face-to-face and online EFL teaching, and training on online computer literacy, are essential to be adopted in order to implement online EFL instruction effectively.

The interview. The EFL teachers suggested some strategies that can be taken in order to implement online instruction. As depicted by the questionnaire results, the EFL teachers deemed that there should be adequate computer-based and Internetbased facilities to implement online EFL instruction. Receiving training for online instruction for both teachers and students was reported to be essential. In addition, 44 teachers considered implementing blended EFL instruction more beneficial than online EFL instruction:

For successful implementation of online courses in EFL, we need both training and facility improvement. Of course, training should be both for EFL teachers and learners. Also, we need to have high-quality and up-to-date online facilities to implement online instruction effectively. (Teacher 11)

This is my belief that the current EFL context of Iran requires the combination of online and face-to-face courses to achieve the utmost efficiency. However, I think it's too early to expect our learners and teachers to accept online courses and adapt their teaching and learning practices to it. (Teacher 27)

Table 4. Strategies to include online instruction.

$N=242$ Mean SD

Computer-based and online facilities should be improved in EFL courses

$4.51 \quad 0.81$

$\begin{array}{llll}\text { Students and teachers should receive training on online computer literacy skills } & 4.19 & 0.82\end{array}$

Online EFL courses should be combined with face-to-face EFL courses 4.1

EFL teachers should receive training on online EFL teaching methodologies and $4.01 \quad 1.2$ principles

$\begin{array}{lrr}\text { Online EFL courses should replace traditional EFL courses } & 2.65 & 0.97\end{array}$

Likert scales: 1 , strongly disagree; 2 , disagree; 3 , undecided; 4, agree; 5 , strongly agree. 
I know that online instruction is a large industry in language teaching nowadays, but having online courses is a good idea provided that it can be supported by face-to-face teaching sessions. (Teacher 2)

\section{Discussion and conclusion}

The findings indicated that the majority of language teachers who participated in this study adopted positive attitudes towards online instruction of EFL. Since teachers occupy pivotal roles in motivating students to use technology for their learning, the positive perspectives of teachers on the implementation of online instruction would facilitate the integration of online instruction in the EFL curriculum in Iran. The findings of this study are commensurate with the previous literature on teachers' perceptions of online instruction which has revealed teachers' acceptance of and satisfaction with online approaches to teaching (Bijeikiené, Rašinskiené, and Zutkiené 2011; Hampel and Hauck 2004; Murday, Ushida, and Chenoweth 2008; Shin and Son 2007). Successful application of technology in EFL instruction requires teachers' positive attitudes (Jones 2001; Dashtestani 2012). In this study, the teachers expressed their preference for implementing blended instruction over online instruction. Teachers' preference for the implementation of blended instruction has also been echoed in the previous research (Bijeikienè, Rašinskienè, and Zutkienè 2011; Hampel and Hauck, 2004; Murday, Ushida, and Chenoweth 2008). It is beneficial to set long-term goals to include blended learning in the EFL programs in Iran. To achieve this aim, educational authorities, teachers, educators and course designers should adopt positive attitudes towards online and blended instruction. Taking language teachers' attitudes towards online instruction into account, educational institutions should pave the way for motivating teachers to include online instruction in their teaching practices. Additionally, both teachers and students should have positive attitudes towards technology use (Jones 2001). Therefore, further research is required to identify students' perspectives on online instruction and their needs and preferences. Certainly, educational authorities and course designers should be cautious about the needs and preferences of teachers and learners and make attempts to meet the needs appropriately and continuously.

Various factors and obstacles might discourage language teachers from implementing online instruction in the Iranian context. One significant barrier to online instruction of EFL in Iran would be a lack of online facilities and equipment. This shortcoming is not exclusively related to the quantity of online facilities but also linked to their quality. Lack of online facilities would be a demotivating factor for both students and teachers. Lack of online facilities has been an impediment to online instruction in other EFL contexts as well (Shin and Son 2007; Toprakci 2002). As much emphasis has been placed on facilitating the incorporation of online and blended instruction into Iranian EFL educational context (Ghafari and Molaei 2011; Goodarzi et al. 2012; Khasseh, Moghaddam, and Jowkar 2009; Tavakoli Khomeini 2009), it is crucial that all educational stakeholders in Iran strive to provide the prerequisites for online instruction. Consequently, both the quality and quantity of online facilities should be improved so that teachers and students become motivated to implement online instruction. At present, it appears that very limited attention is paid to provide and improve online facilities in the Iranian EFL context. If educational authorities are determined to set realistic goals for the future, they will 


\section{R. Dashtestani}

need to consider including and enhancing online and technological instruction in the near future.

To overcome the problem of lack of online instruction facilities, providers of language-teaching institutions, schools and universities may fund teachers and students to have access to mobile devices. More importantly, more needs-analysis studies are required to identify the types of facilities that teachers and students need in order to implement online instruction in EFL courses. Lack of facilities and resources would act as a demotivating factor which discourages teachers and students from implementing online instruction in EFL contexts. Therefore, to provide language teachers with appropriate resources, it is essential that a number of language-teaching stakeholders, including authorities, course designers, providers, supervisors, funders and curriculum planners, implement strategies to eliminate or at least alleviate the problem of resource unavailability.

The other significant obstacle to the implementation of online instruction appears to be the limited level of computer and Internet literacy of language teachers. This finding is compatible with the results of a number of studies which have reported the issue of teachers' low computer literacy levels as a challenge to the implementation of online instruction (e.g., Koo 2008; Murday, Ushida, and Chenoweth 2008; Son, Robb, and Charismiadji 2011). Hampel and Stickler (2005) suggest that for successful and efficient implementation of online instruction in EFL contexts, language teachers should have specific skills and competences which are different from those required for face-to-face instruction. One of those necessary skills is teachers' ability to use various computer software tools and online applications. Several scholars have recommended EFL authorities to include training for skills required for online instruction of languages in mainstream teacher preparation programs (Compton 2009; Hampel and Stickler 2005; Hubbard 2008). Consequently, Iranian EFL teacher educators and authorities can provide training for electronic literacies for the Iranian EFL teachers. Not only can these training courses promote EFL teachers motivation for implementing online instruction, but they can also improve teachers' confidence in the use of online technologies. However, if the inclusion of online instruction teacher training programs is not feasible for teacher educators and educational authorities, continuous workshops and on-the-job training sessions would occupy a pivotal role in improving language teachers' online skills. Obviously, language teachers need to be equipped with both theoretical and practical skills required for the implementation of online instruction in EFL courses. It is also noteworthy that both teachers and students should receive training for their computer and Internet literacy skills. The issue of the need for providing online instruction training for students and teachers was emphasised by Shin and Son (2007). Many teachers and instructors would not be aware of the ways to integrate technology and online instruction in their professional practices.

The EFL teachers perceived that online instruction of EFL would not be interactive. This limitation of online instruction has been pointed out in other studies as well (Carnevale 2004; Hampel and Hauck 2004). However, DeLacey and Leonard (2002) suggest that the implementation of online instruction would improve students' interaction in the classroom. One important feature of e-learning is that students' interaction must be improved and promoted (Rouse 2007). In addition, in online instruction the teachers might not be able to identify some parameters, including students' interaction with the task and themselves, students' use of gestures and body language, and their reactions to questions and the input since there is no face-to-face 
communication (Mills, Yanes, and Casebeer 2009). This lack of interaction might be a severe challenge for many teachers in the digital age (Lindsay 2004). The participants of this study reported that they preferred blended instruction to online instruction. This issue may imply that the teachers believe that face-to-face instruction is more interactive than online instruction. The problem might be directly related to teachers' lack of knowledge of online instruction. Teachers should be able to employ interactive techniques and procedures when implementing online instruction. Definitely, the issue of interaction in online instruction is a complicated one, which requires further consideration and profound insights. Educational authorities and teacher educators should adopt specific measures to change teachers' perceptions on specific aspects of online instruction, including interactivity.

To overcome the issue of lack of interactivity in online instruction, EFL teachers can use several types of technologies to enhance the level of interaction in online instruction. These online tools can be appropriate substitutes for traditional faceto-face communication in the classroom. For example, several research studies have revealed that the use of videoconferencing and web conferencing tools, such as Skype and GotoMeeting, can improve the interactions and computer skills of both students and teachers (Eaton, 2010; Mok and Li 2007; Sardegna and Molle 2010; $\mathrm{Wu}$, Yen, and Marek 2011). EFL teachers should update their knowledge of the software tools and programs which can enhance the level of interactivity in the online EFL course. Obviously, there are various approaches to increasing the level of interaction in online courses.

More importantly, teachers' perspectives on students' lack of appropriate computer literacy needs to be considered by educational authorities and planners in Iran. This issue implies that further research is required to assess Iranian students' computer literacy levels and identify the necessary computer and Internet skills for the effective implementation of online instruction. This finding is commensurate with the results of studies which have shown that EFL students had low levels of computer literacy in the other EFL contexts (Bataineh and Baniabdelrahman 2006; Lockley 2011; Murray and Blyth 2011; O’Neill 2009).

The findings indicated that there are cultural resistances to the implementation of online instruction in Iran. The teachers believed that students might adopt negative attitudes towards online instruction. Thus, it is essential that both teachers and educational authorities in Iran take certain measures to remove cultural barriers to the implementation of online instruction. Since traditional approaches to instruction are dominant in the Iranian educational contexts, much energy and time is required to change the status quo and encourage students to adopt positive attitudes towards online instruction. The implementation of online instruction is unavoidable in the near future and educational systems and institutions which fail to accept this change might become ineffective (Ghafari and Molaei 2011; Goodarzi et al. 2012; Khasseh, Moghaddam, and Jowkar 2009; Tavakoli Khomeini 2009).

The teachers suggested a number of strategies which might facilitate the integration of online instruction in the EFL curricula of Iran. The teachers stated that they needed to be trained for the skills required for the implementation of online instruction. Alternatively, the inclusion of skills related to online instruction in mainstream teacher education programs might be an efficient strategy to improve teachers' levels of confidence and skills required for online instruction (Compton 2009; Hampel and Stickler 2005; Hubbard 2008). Educational authorities and providers should take extreme care to take into consideration both teachers' online 


\section{R. Dashtestani}

skills and methodological knowledge when online EFL instruction is planned to be implemented. Moreover, the majority of teachers believed that online and face-to-face instruction approaches should be combined. Iranian educational authorities should take these strategies into consideration and strive to take appropriate measures to improve the efficiency of online instruction as well as teachers' motivation, confidence and satisfaction accordingly.

Lastly, the issue of online EFL instruction is a significant one, which requires meticulous attention. More importantly, we need to assess the suitability of the implementation of online EFL instruction in various educational contexts and settings. In developing countries, the inclusion of online or blended EFL instruction would provide teachers and students with a plethora of opportunities to improve their teaching and learning practices. Implementing online EFL instruction can contribute to the transformation of traditional teaching approaches to technology-based and interactive instruction.

\section{Limitations of the study}

The conduction of this study was not without limitations. The first limitation was due to the difference between the perceptions of the three sample groups of teachers who participated in this study. The difference between their perceptions was not analysed since the number of teachers from each sample group was not equal and proportionate. As for the second limitation, since access to the Iranian EFL authorities and course designers was not possible for the researcher, they were not included in the sample. However, the inclusion of educational authorities and course designers could provide valuable insights into identifying challenges and obstacles to the implementation of online instruction in Iran.

\section{Biography}

Biodata: Reza Dashtestani is a doctoral student in Applied Linguistics at the University of Tehran. His research interests include English for Specific/Academic Purposes (ESP/EAP), CALL, electronic literacies, distance education and interactive learning.

\section{References}

Allen, M. et al. (2002) 'Comparing student satisfaction with distance education to traditional classroom in higher education: a meta-analysis', American Journal of Distance Education, vol. 16, no. 2, pp. 83-97.

Anderson, D. L., Fisher, K. M. \& Norman, G. J. (2002) 'Development and evaluation of the conceptual inventory of natural selection', Journal of Research of Science Teaching, vol. 39, no. 10 , pp. $952-978$.

Aydin, S. (2007) 'Attitudes of EFL learners towards the Internet', Age, vol. 22, no. 6, pp. 5-2.

Bataineh, R. F. \& Baniabdelrahman, A. A. (2006) 'Jordanian EFL students' perceptions of their computer literacy', International Journal of Education and Development using Information and Communication Technology, vol. 2, no. 2, pp. 35-50.

Beatty, B. \& Ulasewicz, C. (2006) 'Faculty perspectives on moving from blackboard to the module learning management system', Research and Practice to Improve Learning, vol. 50, no. 4 , pp. $36-45$.

Benson, V., Anderson, D. \& Ooms, A. (2011) 'Educators' perceptions, attitudes and practices: blended learning in business and management education', Research in Learning Technology, vol. 19 , no. 2 , pp. $143-154$. 
Best, W. B. \& Kahn, J. V. (2005) Research in Education, 10th edn, Pearson Education, Cambridge, UK.

Bijeikienė, V., Rašinskienè, S. \& Zutkienè, L. D. (2011) 'Teachers' attitudes towards the use of blended learning in general English classroom', Kalbu Studijos, vol. 18, pp. 122-127.

Britt, R. (2006) 'Online education: a survey of faculty and students', Radiologic Technology, vol. 77 , no. 3 , pp. $183-190$.

Can, T. (2009) 'Learning and teaching languages online: a constructivist approach', NovitasROYAL, vol. 3 , no. 1 , pp. $60-74$.

Carnevale, D. (2004) 'Educational technology fails to deliver on its promises, report says', The Chronicle of Higher Education, [online] Available at: http://chronicle.com/prm/daily/2004/ 06/2004062401n.htm

Chenoweth, N. A. \& Murday, K. (2003) 'Measuring student learning in an online French course', CALICO Journal, vol. 20, no. 2, pp. 285-314.

Chou, C. C. (2010) 'Student perceptions and pedagogical applications of e-learning tools in online course', In Handbook of Research on Practices and Outcomes in E-Learning: Issues and Trends, eds. H. Hao Yang \& S. Chi-Yin Yuen, Hershey, PA, pp. 440-454.

Compton, L. K. (2009) 'Preparing language teachers to teach language online: a look at skills, roles, and responsibilities', Computer Assisted Language Learning, vol. 22, no. 1, pp. 73-99.

Corda, A. \& Stel, M. (2004) 'Web-based CALL for Arabic: constraints and challenges', CALICO Journal, vol. 21, no. 3, pp. 485-496.

Dashtestani, R. (2012) 'Barriers to the implementation of CALL in EFL courses: Iranian EFL teachers' attitudes and perspectives', The JALT CALL Journal, vol. 8, no. 2, pp. 55-70.

Dawley, L. (2007) The Tools for Successful Online Teaching, Information Science, Hershey, PA.

DeLacey, B. \& Leonard, D. (2002) 'Case study on technology and distance education at the Harvard Business School', Educational Technology and Society, vol. 5, no. 2, pp. 13-28.

Eaton, S. E. (2010) 'How to use Skype in the ESL/EFL classroom', The Internet TESL Journal, vol. 16, no.11, [online] Available at: iteslj.org/Techniques/Eaton-UsingSkype.html

Fathi Vajargah, K. \& Khoshnoodifar, M. (2013) 'Toward a distance education based strategy for internalization of the curriculum in higher education of Iran', The Turkish Online Journal of Educational Technology, vol. 12, no. 1, pp. 147-160.

Fish, W. W. \& Gill, P. B. (2009) 'Perceptions of online instruction', The Turkish Online Journal of Educational Technology, vol. 8, no. 1, pp. 53-64.

Ghafari, H. \& Molaei, M. A. (2011) 'Quality and satisfaction of blended-style education in economic courses', World Applied Sciences Journal, vol. 12, no. 3, pp. 287-289.

Gharehbakloo, M. R. (2005) 'Technologies and frameworks of distance learning in Iran: needs and challenges', [online] Available at: http://www.niitcrcs.com/iccs/papers/2005_10.pdf

Gold, S. (2001) 'A constructivist approach to online training for online teachers', Journal of Asynchronous Learning Networks, vol. 5, no. 1, pp. 35-57.

Goodarzi, M. et al. (2012) 'Impact of distance education via mobile phone text messaging on knowledge, attitude, practice and self-efficacy of patients with type 2 diabetes mellitus in Iran', Journal of Diabetes \& Metabolic Disorders, vol. 11, no. 1, pp. 1-8.

Hammonds, S. (2003) 'Impact of internet-based teaching on student achievement', British Journal of Educational Technology, vol. 34, no. 1, pp. 95-98.

Hampel, R. \& Hauck, M. (2004) 'Towards an effective use of audio conferencing in distance language courses', Language Learning \& Technology, vol. 8, no. 1, pp. 66-82.

Hampel, R. \& Stickler, U. (2005) 'New skills for new classrooms: training tutors to teach languages online', Computer Assisted Language Learning, vol. 18, no. 4, pp. 311-326.

Hill, J. R. (2002) 'Overcoming obstacles and creating connections: community building in Web-based learning environments', Journal of Computing in Higher Education, vol. 14, no. 1 , pp. $67-86$.

Hofmann, D. W. (2002) 'Internet-based distance learning in higher education', Tech Directions, vol. 62 , no. 1 , pp. $28-32$.

Hubbard, P. (2008) 'CALL and the future of language teacher education', CALICO Journal, vol. 25 , no. 2 , pp. $175-188$.

Irani, T. \& Telg, R. (2002) 'Gauging distance education students' comfort level with technology and perceptions of self-assessment and technology training initiatives', Paper presented at the Agricultural Communicators in Education (ACE) Conference, Savannah, GA. 


\section{R. Dashtestani}

Isman, A. \& Dabaj, F. (2004) 'Attitudes of students towards Internet', Turkish Online Journal of Distance Education, vol. 5, no. 4, [online] Available at: http://tojde.anadolu.edu.tr/ tojde16/articles/dabaj.htm

Jones, J. (2001) 'CALL and the responsibilities of teachers and administrators', ELT Journal, vol. 55, no. 4, pp. 360-367.

Khasseh, A., Moghaddam, H. S. \& Jowkar, A. (2009) 'Distance education and the role of library services in Iran: a case study of Shiraz University Distance Learners', Library Hi Tech News, vol. 26, no. 7, pp. 11-14.

Kim, K. \& Bonk, C. J. (2006) 'The future of online teaching and learning in higher education: the survey says', Educause Quarterly, vol. 29, no. 4, p. 22.

Koo, A. C. (2001) 'A study on teachers' perception towards computer-mediated collaborative learning', Paper presented at Africa Connects Conference, Cape Town, South Africa.

Koo, A. C. (2008) 'Factors affecting teachers' perceived readiness for online collaborative learning: a case study in Malaysia', Educational Technology \& Society, vol. 11, no. 1, pp. 266-278.

Lavooy, M. J. \& Newlin, M. H. (2003) 'Computer mediated communication: online instruction and interactivity', Journal of Interactive Learning Research, vol. 14, no. 2, pp. 157-165.

Levy, M. (2009) 'Technologies in use for second language learning', The Modern Language Journal, vol. 93, pp. 769-782.

Li, C. S. \& Irby, B. (2008) 'An overview of online education: attractiveness, benefits, challenges, concerns and recommendations', College Student Journal, vol. 42, no. 2, pp. 449-458.

Lindsay, G. (2004) 'Pupil participation: the NASEN policy', Support for Learning, vol. 19, no. 4, pp. 194-195.

Lockley, T. (2011) 'Japanese students' experience of ICT and other technology prior to university: a survey', The JALT CALL Journal, vol. 7, no. 1, pp. 93-102.

Mackey, A. \& Gass, S. M. (2005) Second Language Research: Methodology and Design, Lawrence Erlbaum Associates, Mahwah, NJ.

Madaus, J. (2013) 'Teaching online and blended courses: perceptions of faculty', The Journal of Applied instructional Design, vol. 3, no. 1, pp. 53-62.

Mills, S. J., Yanes, M. J. \& Casebeer, C. M. (2009) 'Perceptions of distance learning among faculty of a college of education', MERLOT Journal of Online Learning and Teaching, vol. 5, no. 1 , pp. 19-28.

Mok, I. \& Li, Q. (2007) 'Integrating videoconferencing technology into classroom practices as a way to work with others in the larger community', Malaysian Journal of Distance Education, vol. 9, no. 2, pp. 107-124.

Murday, K., Ushida, E. \& Chenoweth, N. A. (2008) 'Learners' and teachers' perspectives on language online 1', Computer Assisted Language Learning, vol. 21, no. 2, pp. 125-142.

Murphy, K. R. \& Davidshofer, C. O. (2001) Psychological Testing. Upper Saddle River, NJ, Prentice Hall.

Murray, A. \& Blyth, A. (2011) 'A survey of Japanese university students' computer literacy levels', The JALT CALL Journal, vol. 7, no. 3, pp. 307-318.

O’Neill, S. (2009) 'EFL proficiency level and differences in Japanese secondary school students' views on the need for pedagogical change', International Journal of Pedagogies and Learning, vol. 5, no. 1, pp. 49-71.

Petrides, L. A. (2002) 'Web-based technologies for distributed (or distance) learning: creating learning-centered educational experiences in the higher education classroom', International Journal of Instructional Media, vol. 29, no. 1, pp. 69-77.

Poole, D. M. (2000) 'Student participation in a discussion-oriented online course: a case study', Journal of Research on Computing in Education, vol. 33, no. 2, pp. 162-177.

Puteh, M. B. (2002) 'Language teaching via the Internet: perception of English language teachers of higher learning institutions', Jurnal Teknikal \& Kajian Sosial, vol. 1, pp. 40-53.

Reeves, K. \& Brown, B. (2002) 'Online adjuncts', School Administrator, vol. 59, pp. 32-37.

Richardson, J. \& Newby, T. J. (2006) 'The role of students' cognitive engagement in online learning', American Journal of Distance Education, vol. 20, no. 1, pp. 23-37.

Rouse, D. P. (2007) 'Computer-assisted instruction: an effective instructional method', Teaching Learning in Nursing, vol. 2, pp. 138-143. 
Sam, H. K., Wah, T. K. \& Leong, L. K. (2007) 'Pre-service teachers' perceptions of an online mathematical problem solving course: a constructivist approach', Paper presented at Proceedings of Ascilite, Singapore.

Sampson, N. (2003) 'Meeting the needs of distance learners', Language Learning \& Technology, vol. 7, no. 3, pp. 103-118.

Sardegna, V. G. \& Molle, D. (2010) 'Videoconferencing with strangers: teaching Japanese EFL students verbal backchannel signals and reactive expressions', Intercultural Pragmatics, vol. 7, no. 2, pp. 279-310.

Scida, E. E. \& Saury, R. E. (2006) 'Hybrid courses and their impact on student and classroom performance: a case study at the University of Virginia', CALICO Journal, vol. 23, no. 3, pp. 517-531.

Shin, H. J. \& Son, J. B. (2007) 'EFL teachers' perceptions and perspectives on internet-assisted language teaching', Computer-Assisted Language Learning Electronic Journal, vol. 8, no. 2, [online] Available at: http://eprints.usq.edu.au/1924/1/Shin_Son.pdf

Son, J. B. (2011) 'Online tools for language teaching', TESL-EJ, vol. 15, no. 1, pp. 1-12.

Son, J.-B., Robb, T. \& Charismiadji, I. (2011) 'Computer literacy and competency: a survey of Indonesian teachers of English as a foreign language', $C A L L-E J$, vol. 12, no. 1, pp. 26-42.

Song, L. et al. (2004) 'Improving online learning: student perceptions of useful and challenging characteristics', Internet \& Higher Education, vol. 7, no. 1, pp. 59-70.

Stickler, U. \& Hauck, M. (2006) 'What does it take to teach online? Towards pedagogy for online language teaching and learning', CALICO Journal, vol. 23, no. 3, pp. 463-475.

Tavakoli Khomeini, N. (2009) 'The impact of open distance education on breaking cultural barriers and creating employment in Iran', [online] Available at: http://www.ou.nl/Docs/ Campagnes/ICDE2009/Papers/Final_Paper_048Khomeini.pdf

Taylor, T. L. (2003) 'Multiple pleasures women and online gaming. Convergence', The International Journal of Research into New Media Technologies, vol. 9, no. 1, pp. 21-46.

Toprakci E. (2002) 'Obstacles at integration of schools into information and communication technologies by taking into consideration the opinions of the teachers and principals of secondary schools in Turkey', E-Journal of Instructional Science and Technology, vol. 9, no. 1 , pp. $1-16$.

Thurmond, V. A. et al. (2002) 'Evaluation of student satisfaction: determining the impact of a Web-based environment by controlling for student characteristics', The American Journal of Distance Education, vol. 16, no. 3, pp. 169-190.

Vonderwell, S. (2003) 'An examination of asynchronous communication experiences and perspectives of students in an online course: a case study', Internet and Higher Education, vol. 6, pp. 77-90.

Warschauer, M. (2010) 'New tools for teaching writing', Language Learning \& Technology, vol. 14, no. 1 , pp. 3-8.

Woo, Y. \& Reeves, T. C. (2007) 'Meaningful interaction in web-based learning: a social constructivist interpretation', The Internet and Higher Education, vol. 10, no. 1, pp. 15-25.

Wu, W. C. V., Yen, L. L. \& Marek, M. (2011) 'Using online EFL interaction to increase confidence, motivation, and ability', Educational Technology \& Society, vol. 14, no. 3, pp. $118-129$.

Yang, S. C. (2001) 'Language learning on the world wide web: an investigation of EFL learners' attitudes and perceptions', Journal of Educational Computing Research, vol. 24, no. 2, pp. $155-181$.

Yusof, A. M. et al. (2011) 'Teachers' perceptions on the blended learning environment for special needs learners in Malaysia: a case study', Paper presented at 2nd International Conference on Education and Management Technology, Shanghai, China. 